\title{
Zinc Blockade of SOS Response Inhibits Horizontal Transfer of Antibiotic Resistance Genes in Enteric Bacteria
}

OPEN ACCESS

Edited by:

You-Hee Cho,

Cha University, South Korea

Reviewed by:

Chulhee Choi,

Chungnam National University, South Korea

Yang Zhang,

University of Pennsylvania United States

*Correspondence: John K. Crane

jcrane@buffalo.edu

Specialty section:

This article was submitted to

Clinical Microbiology,

a section of the journal

Frontiers in Cellular and Infection

Microbiology

Received: 01 August 2018 Accepted: 05 November 2018 Published: 21 November 2018

Citation:

Crane JK, Cheema MB, Olyer MA and Sutton MD (2018) Zinc Blockade of SOS Response Inhibits Horizontal Transfer of Antibiotic Resistance

Genes in Enteric Bacteria.

Front. Cell. Infect. Microbiol. 8:410. doi: 10.3389/fcimb.2018.00410

\begin{abstract}
John K. Crane ${ }^{1 *}$, Muhammad B. Cheema ${ }^{1}$, Michael A. Olyer ${ }^{1}$ and Mark D. Sutton ${ }^{2}$
${ }^{1}$ Division of Infectious Diseases, Department of Medicine, Jacobs School of Medicine and Biomedical Sciences, University at Buffalo, Buffalo, NY, United States, ${ }^{2}$ Department of Biochemistry, Jacobs School of Medicine and Biomedical Sciences, University at Buffalo, Buffalo, NY, United States
\end{abstract}

The SOS response is a conserved response to DNA damage that is found in Gram-negative and Gram-positive bacteria. When DNA damage is sustained and severe, activation of error-prone DNA polymerases can induce a higher mutation rate than is normally observed, which is called the SOS mutator phenotype or hypermutation. We previously showed that zinc blocked the hypermutation response induced by quinolone antibiotics and mitomycin C in Escherichia coli and Klebsiella pneumoniae. In this study, we demonstrate that zinc blocks the SOS-induced development of chloramphenicol resistance in Enterobacter cloacae. Zinc also blocked the transfer of an extended spectrum beta-lactamase (ESBL) gene from Enterobacter to a susceptible E. coli strain. A zinc ionophore, zinc pyrithione, was $\sim 100$-fold more potent than zinc salts in inhibition of ciprofloxacin-induced hypermutation in E. cloacae. Other divalent metals, such as iron and manganese, failed to inhibit these responses. Electrophoretic mobility shift assays (EMSAs) revealed that zinc, but not iron or manganese, blocked the ability of the E. coli RecA protein to bind to single-stranded DNA, an important early step in the recognition of DNA damage in enteric bacteria. This suggests a mechanism for zinc's inhibitory effects on bacterial SOS responses, including hypermutation.

\footnotetext{
Keywords: antibiotic resistance, RecA, electrophoretic mobility shift assay, Enterobacter cloacae, extended spectrum beta lactamase, CTX-M27, Zinc pyrithione
}

\section{INTRODUCTION}

The term "SOS response" as descriptor of a bacterial reactions to DNA damage was coined about 1975, the same year that the ship Edmund Fitzgerald sank in Lake Superior without sending out an SOS distress call. The SOS response triggers a constellation of changes in the bacterial cell, including cellular elongation, suspension of cell division, induction of DNA repair pathways, induction of latent bacteriophages, expression of bacteriophage-encoded toxins, and increased expression of error-prone DNA polymerases (Goodman, 2002). The latter underlies the increased mutation rate observed when the SOS response is strongly induced.

Recently, several laboratories showed that sublethal concentrations of certain SOS-inducing antibiotics induced resistance to other, unrelated antibiotics (Kohanski et al., 2010; Song et al., 2016; Bunnell et al., 2017). Their work and that of others have led to increased interest in whether SOS inhibitors could block emergence of antibiotic resistance (Nautiyal et al., 2014; Alam et al., 2016). 
We initially became interested in the SOS response because of its role in inducing the expression of the Shiga toxins in Shiga-toxigenic Escherichia coli (STEC), because antibiotics induce production of the Shiga toxins Stx1 and Stx2, resulting in a worsening of the disease. Since previous work showed that zinc inhibited Stx production in STEC, we wondered if zinc's inhibitory effects were mediated by inhibition of the SOS response, and found that indeed they were (Crane et al., 2014). Indeed, zinc's inhibitory effects on the SOS response also blocked hypermutation in E. coli and Klebsiella strains (Bunnell et al., 2017).

Beaber et al. previously showed that induction of the SOS response with mitomycin $\mathrm{C}$ or ciprofloxacin dramatically increased the rate of horizontal antibiotic resistance transfer from $E$. coli to Vibrio cholerae, and from one strain of $V$. cholerae to another (Beaber et al., 2003). In this study, we first tested whether the inhibitory effects of zinc salts on SOS also extended to another member of the Enterobacteriaceae family, Enterobacter cloacae. We next tested whether zinc ionophores, such as A23187 or zinc pyrithione, would show increased potency against the hypermutation response. We also tested whether zinc could block the transfer of antibiotic resistance from Enterobacter to a susceptible E. coli recipient strain. Zinc salts and zinc pyrithione blocked hypermutation in E. cloacae and zinc also blocked horizontal transfer of $ß$-lactam resistance to another, unrelated E. coli strain. Last, we developed an electrophoretic mobility shift assay (EMSA) to determine if metals blocked binding of RecA to ssDNA. We demonstrated that zinc, but not other divalent metals, blocked the ability of RecA to bind to ssDNA in this EMSA.

\section{MATERIALS AND METHODS}

\section{Materials}

Mitomycin C, ciprofloxacin (cipro), chloramphenicol (chloramph), zinc acetate, zinc pyrithione, A23187, agarose, ATP, ATP- $\gamma-S$, Sypro Orange protein stain, and copper phthalocyanine tetrasulfonate were from Sigma-Aldrich (St. Louis, MO). Gradient-impregnated antibiotic test strips were purchased from Liofilchem, Inc., (Abruzzi, Italy, and Waltham. MA). Copper pyrithione was from Combi-Blocks, San Diego, CA, while ceftazidime (ceftaz) was purchased from TCI, Tokyo, Japan. DMEM-F12 medium was from Gibco, Inc., Grand Island, NY, a subsidiary of Thermo-Fisher. DNase I was from Worthington Biochemical Corp., Lakewood, NJ. Purified RecA protein was purchased from New England Biolabs (NEB, Boston, MA). Blue Juice loading dye, SYBR-Safe DNA dye, and the $100 \mathrm{bp}$ DNA ladder were from the Invitrogen division of Thermo-Fisher.

Bacterial Strains Used. Bacterial strains are described in Table 1.

\section{Hypermutation in E. cloacae Bacteria}

As previously described, bacteria were grown overnight in LB broth at $37^{\circ} \mathrm{C}$ with $300 \mathrm{rpm}$ shaking, then subcultured into DMEM-F12 broth medium for induction of hypermutation. The DMEM/F12 medium was supplemented with $18 \mathrm{mM} \mathrm{NaHCO}_{3}$ and $25 \mathrm{mM}$ additional HEPES, $\mathrm{pH}$ 7.4, but omitted serum and antibiotics. The usual dilution from overnight was 1:100 into DMEM-F12, but this was varied if needed. After $75 \mathrm{~min}$, the culture was divided into separate tubes and ciprofloxacin was added to a concentration equivalent to $1 / 2$ to $3 / 4$ of the MIC for that strain. Differences in the concentration of ciprofloxacin used resulted in differences in the antibiotic resistance frequencies observed. Metals such as zinc were added at this time, and incubation was continued with $300 \mathrm{rpm}$ shaking. Four hours after initiation of the subculture, the culture turbidities were measured as $\mathrm{OD}_{600}$ on a spectrophotometer, and serial dilutions were quickly plated onto LB agar to measure the total bacterial counts in each condition. In addition, 100-200 $\mu \mathrm{l}$ of undiluted culture was plated in triplicate onto plates of $\mathrm{LB}+20 \mathrm{mg} / \mathrm{L}$ $(20 \mu \mathrm{g} / \mathrm{mL})$ chloramphenicol, a concentration 5 times the MIC of E_clo_Niagara. Antibiotic resistance frequencies were calculated as the (CFU of antibiotic resistant colonies $/ \mathrm{mL}) \div(\mathrm{CFU}$ of total colonies $/ \mathrm{mL}$ ). In some cases, the antibiotic resistance frequency was multiplied by $10 \mathrm{e} 6$ and expressed as "chloramphenicol resistance frequency per million" as previously shown, and in other cases these results were converted to a logarithmic scale. When zero colonies were observed on any of the triplicate plates, the lower limit of detection was calculated as if 1 colony had been observed; this was often the case in the control cultures, i.e., bacteria not exposed to any SOS-inducing antibiotic.

\section{Cross-Species (Horizontal) Transfer of Antibiotic Resistance}

In order to test for the transfer of genetic material from the ceftaz $^{\mathrm{R}}$ E. cloacae to Chloramph ${ }^{\mathrm{R}}$ fluorescent E. coli strain EC43, or vice versa, both strains were grown up in LB broth overnight, then both were subcultured into DMEM-F12 liquid medium. After $75 \mathrm{~min}$, ciprofloxacin was added at the appropriate concentrations for each strain. At this time, metals such as zinc were also added. At the $4 \mathrm{~h}$ time point, the culture turbidities were read as $\mathrm{OD}_{600}$, and then dilutions were made in order to determine the total number of bacteria of each species in their separate cultures. Bacteria were then mixed in a 1:1 ratio, centrifuged at $1,600 \mathrm{~g}$ for $10 \mathrm{~min}$, and then the bacteria were allowed to stand on the bench top at room temperature. After the bacteria had incubated together in the centrifuged pellets, the pellets were resuspended, and then plated on LB + $6 \mu \mathrm{g} / \mathrm{mL}$ ceftazidime and $20 \mu \mathrm{g} / \mathrm{mL}$ chloramphenicol, and the plates were inspected on the UV transilluminator box for doubleresistant, green-fluorescing colonies. In pilot experiments, we tested mixing the two bacterial strains for 3,4 , and $6 \mathrm{~h}$, but we never observed any transconjugant colonies at these durations of bacterial contact. Finally, we therefore allowed the centrifuged bacterial mixtures to stand on the bench top at room temperature for $20 \mathrm{~h}$, and with this longer duration we did observe putative transconjugant colonies, meaning doubleresistant, green-fluorescing colonies. Putative transconjugant colonies were picked and re-streaked on LB with ceftazidime + chloramphenicol. Biochemical tests were next performed to determine if the putative transconjugant colonies were $E$. coli that had gained resistance to ceftazidime, or E. cloacae that 
TABLE 1 | Description of bacterial strains used.

\begin{tabular}{|c|c|c|c|c|c|}
\hline & Description & $\begin{array}{c}\text { Ciprofloxacin MIC on } \\
\text { DMEM, mg/L }\end{array}$ & $\begin{array}{c}\text { Chloramphenicol MIC on } \\
\text { LB agar, } \mathrm{mg} / \mathrm{L}\end{array}$ & $\begin{array}{l}\text { Ceftazidime MIC on } \\
\text { LB agar, } \mathrm{mg} / \mathrm{L}\end{array}$ & Comments \\
\hline \multicolumn{6}{|c|}{ ENTEROBACTER STRAINS } \\
\hline $\begin{array}{l}\text { Enterobacter cloacae } \\
\text { E_clo_Niagara }\end{array}$ & $\begin{array}{l}\text { Wild-type, clinical isolate, } \\
\text { bloodstream infection, ESBL }\end{array}$ & 0.064 & 4 & $\begin{array}{l}6 \text { on LB; } \geq 16 \text { on } \\
\text { Muller-Hinton }\end{array}$ & $\begin{array}{l}\text { "ESBL" or extended } \\
\text { spectrum beta- lactamase } \\
\text { producer; + }{ }^{\text {for }} \text { blaCTX-M27 }\end{array}$ \\
\hline BAA-1143 & ATCC type strain & 0.006 & 8 & 96 & $\begin{array}{l}\text { AmpC chromosomal } \\
\text { beta-lactamase; from } \\
\text { Microbiologics, St. Cloud, } \\
\text { MN }\end{array}$ \\
\hline \multicolumn{6}{|l|}{ E. coli STRAINS } \\
\hline E. coli EC43 & $\begin{array}{l}\text { O157:H7 } \\
\text { (pGFP-UV-Chloramph }{ }^{\mathrm{R}} \text { ). } \\
\text { Expresses green fluorescent } \\
\text { protein (GFP) from plasmid; } \\
\text { Chloramphenicol-resistant. }\end{array}$ & 0.008 & $>40$ & 0.064 & $\begin{array}{l}\text { Microbiologics, St. Cloud, } \\
\text { MN; traceable to FDA strain } \\
\text { ESC1177 }\end{array}$ \\
\hline
\end{tabular}

had developed chloramphenicol resistance and also acquired the plasmid expressing GFP. The biochemical tests done to distinguish Enterobacter from E. coli included indole production, acid production by the Methyl Red test, Voges-Proskauer test for acetoin production, and streaking on eosin methylene blue (EMB) agar. In all cases the putative transconjugants were E. coli that had become resistant to ceftazidime.

\section{Testing for Beta-Lactamase-Encoding Genes in Enterobacter and in E. coli Transconjugants}

We extracted total DNA from Enterobacter E_clo_Niagara and from the putative E. coli transconjugants that had acquired Blactam resistance using the AllPrep Bacterial DNA Kit from Qiagen (Hilden, Germany and Waltham, MA) according to the manufacturer's instructions. Purified DNA was sent to ID Genomics, Seattle, WA, for PCR detection of the extended spectrum ß-lactamase genes. PCR assays using broad-range primers initially identified the ß-lactamase as a member of CTX$\mathrm{M}$ family, and then specific primers indicated the $B$-lactamase was a CTX-M27. This "head start" from ID Genomics allowed us to then conduct our own PCR assays.

\section{PCR Detection of CTX-M27 in E. cloacae and in Putative E. coli Transconjugants/Transformants}

Plasmid DNA was prepared from the donor strain, E_clo_Niagara, recipient strain EC43, and from the putative transconjugant $E$. coli strains that emerged from the interspecies gene transfer experiments, using Qiagen Midi-Plasmid preparation kits (Waltham, MA). Primer pairs directed against the gene $b l a_{\mathrm{CTX}-\mathrm{M} 27}$, encoding the extended spectrum betalactamase CTX-M27, were used for PCR and are shown in Table 2A. PCR was conducted on a Bio-Rad CFX96 real-time PCR machine using Bio-Rad iTaq Universal SYBR Green Master Mix in a final volume of $20 \mu \mathrm{L}$; Primer concentration was $0.5 \mu \mathrm{M}$, and $5 \mu \mathrm{L}$ of the plasmid DNA prepared from each strain
TABLE 2 | Oligonucleotides used.

(A) PCR primers used to amplify plasmid DNA for CTX-M27 beta lactamase.

Primers Amplicon size, b.p.Comment

Forward 158 From (Szczepanowski et al.,

CTGGAGAAAAGCAGCGGAG

2009), Supplemental Data

Reverse

TGCTITGCGTTCACTCTG

Forward $257 \quad$ Designed using Primer

GCGACAATACCGCCATGAAC BLAST tool based on

Reverse

CGTATTGCCTITGAGCCACG

Accession No. AY156923,

from Bonnet (2004) (https://

www.ncbi.nlm.nih.gov/)

(B) Fluorescently labeled oligonucleotide used for electrophoretic mobility shift assay.

This 38-mer oligonucleotide was labeled at the $5^{\prime}$ end with 6- FAM (fluorescein)

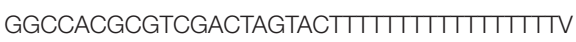

was used as the template for 35-39 PCR cycles using a 3-Step amplification protocol.

\section{Electrophoretic Mobility Shift (EMSA; "Gel-Shift") Assay for RecA Binding to ssDNA}

Purified RecA protein from NEB was used for EMSA along with 10X Assay buffer (Tris acetate, $\mathrm{pH} 7.8$, with magnesium) supplied by the manufacturer. To test for binding to ssDNA, a fluorescently labeled oligonucleotide was purchased from Integrated DNA Technologies, Inc., Coralville, IA. This 38mer oligonucleotide was labeled at the $5^{\prime}$ end with 6-FAM (fluorescein) and the sequence is shown in Table 2B.

To test for RecA-DNA binding, we first did pilot experiments to determine how much fluorescent oligonucleotide was needed to produce a visible fluorescent band on agarose gels. We found that using $5 \mu \mathrm{M}$ fluorescent oligonucleotide gave a visible band when $15 \mu \mathrm{L}$ were loaded on an agarose gel. We next did pilot 
experiments to determine what molar ratio of RecA protein to oligonucleotide was needed to observe any gel shift.

The binding assay was carried out in duplicate or triplicate in $15 \mu \mathrm{L}$ final volume in conical-bottomed 96-well plates kept on ice during reagent addition. The fluorescent oligonucleotide in assay buffer was added first, followed by zinc or other metals added to final concentrations of $0.1-1 \mu \mathrm{M}$. In addition, ATP or ATP- $\gamma$-S was added as noted to achieve a final concentration of $0.3 \mathrm{mM}$. Last, RecA protein was added from a concentrated stock to achieve the appropriate ratio relative to ssDNA. This ratio was varied to obtain RecA: oligonucleotide ratios of $2: 1$ to $5: 1$, as indicated in the Figure Legends. After addition of RecA, the plate was moved to the $37^{\circ}$ incubator where it was sandwiched between pre-warmed metal blocks to speed heat transfer to the samples, and binding was allowed to proceed for $15 \mathrm{~min}$. After the incubation, $2 \mu \mathrm{L}$ of $10 \mathrm{X}$ "Blue Juice" loading dye was added to the samples, and then samples were loaded into the wells of an agarose gel (1.5\% agarose in $1 \mathrm{X}$ TAE buffer, with SYBR-Safe DNA stain added to be able to visualize the DNA ladder).

Electrophoresis was carried out at $135 \mathrm{~V}$ for $35 \mathrm{~min}$. After electrophoresis, the gel was visualized on the Gel-Doc E-Z fluorescent imager (Bio-Rad) using the Blue illuminator plate and the settings for SYBR Green, which also work for fluorescein. In some experiments, zinc or other metals were added to the agarose gel at the same concentration as that added to the binding assay. In this case, we used plastic rulers cut to the correct length in order to have some samples running in gel lanes with metal incorporated into the gel itself (Supplemental Figure 1). For quantitation, the image files from the Gel-Doc EZ were "inverted" to produce dark bands on a light background, then quantitated using Un-Scan-It Gel software for the MacIntosh computer (Silk Scientific, Orem, UT).

\section{Measurement of Extracellular DNA}

DNA released into culture supernatants by SOS-inducing treatments was measured in a UV spectrophotometer by $\mathrm{A}_{260} / \mathrm{A}_{280}$ ratio.

\section{Statistical Analysis}

Data shown are means $\pm \mathrm{SD}$. Tests of significance were by analysis of variance (ANOVA), using Dunnett's test for multiple comparisons. Graphs were produced using GraphPad Prism (San Diego, CA).

\section{RESULTS}

\section{Testing for Induction of Hypermutation in Enterobacter cloacae Strain E_clo_Niagara}

Initial experiments were performed to see if ciprofloxacin could induce hypermutation to the unrelated antibiotic, chloramphenicol, in E_clo_Niagara. For these experiments we used a chloramphenicol concentration five times the starting MIC for this strain. Figure 1A shows that a sublethal concentration of ciprofloxacin did greatly increase the chloramphenicol resistance frequency in this strain, and this increase was reversed by zinc acetate in a dose-dependent fashion. As previously observed, however, $200 \mu \mathrm{M}$ zinc acetate was needed to observe strong inhibition of the mutator response (Figure 1A). In addition to zinc, $\mathrm{CuSO}_{4}$, and $\mathrm{CoCl}_{2}$ also were able to inhibit the hypermutation response (Figure 1B), but they were less potent than zinc, as we previously observed with E. coli and Klebsiella (Bunnell et al., 2017). In contrast to zinc, iron (as $\mathrm{FeSO}_{4}$ ), and manganese did not inhibit ciprofloxacininduced hypermutation (Figure $\mathbf{1 C}$; data not shown for $\mathrm{MnCl}_{2}$ ). Interestingly, gallium nitrate also had a mild inhibitory effect on ciprofloxacin-induced hypermutation, even though gallium is a trivalent rather than divalent element.

We next tested whether metal ionophores, such as A23187, or zinc pyrithione, could improve the potency of zinc against the hypermutation response. Our results with A23187 plus zinc were unexpectedly negative, because A23187 alone, in the absence of any metal, consistently increased ciprofloxacin-induced mutation to chloramphenicol resistance (Supplemental Figure 2A, middle bar). Compared to zinc acetate alone, the addition of $100 \mu \mathrm{M}$ A23187 unexpectedly reduced the potency of zinc (dose-response curve shifted to the right, Supplemental Figure 2B). These results may be consistent with A23187 acting more as a zinc chelator than as a zinc ionophore in E_clo_Niagara. Indeed, most of the literature on A23187 in bacterial systems has been with Gram-positive rather than Gram-negative bacteria, and it may be that A23187 is unable to conduct zinc across the double membranes of enteric Gram-negative bacteria.

Despite the unexpected results with A23187 + zinc, zinc pyrithione (ZPT) showed much more promise as an inhibitor of SOS-induced hypermutation. ZPT inhibited ciprofloxacin-induced hypermutation at concentrations near $1 \mu \mathrm{M}$ (Figures 2A,B). While copper pyrithione (CuPT) is often viewed as more toxic to living cells than $\mathrm{ZPT}$ (Bao et al., 2014), we found that ZPT was $\sim 4$-fold more potent than CuPT in its ability to inhibit bacterial growth (Figure 2C). Similarly, ZPT was better than CuPT in blocking the mutator response (Figure 2D). Direct comparison of zinc acetate to ZPT showed that ZPT was $\sim 100$ fold ( 2 logs) more potent than zinc acetate in inhibition of SOS-induced hypermutation (Figures 2E,F). The high potency of ZPT against the SOS response might allow the effects of zinc to be exploited in situations where concentrations of zinc acetate as high as $0.2 \mathrm{mM}$ cannot be achieved.

\section{Testing for Horizontal, Inter-species Gene Transfer in Enteric Bacteria}

Having shown that the SOS response could be induced in E_clo_Niagara, we next tested whether SOS induction could trigger transfer of antibiotic resistance elements between species, as shown by Beaber et al. (2003). In contrast to the study by Beaber et al., who worked with $V$. cholerae, an organism that is naturally competent for uptake of extracellular DNA, E. coli and related enterics are not naturally competent, and although they can take up DNA from the environment, such DNA is often degraded and used as food rather than incorporated into their genomes (Finkel and Kolter, 2001; Chen and Dubnau, 2004; Palchevskiy and Finkel, 2006). Therefore, it was unclear whether 
A

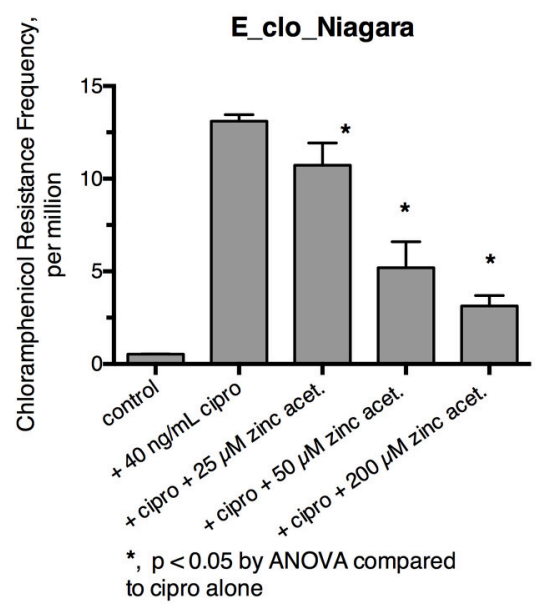

C

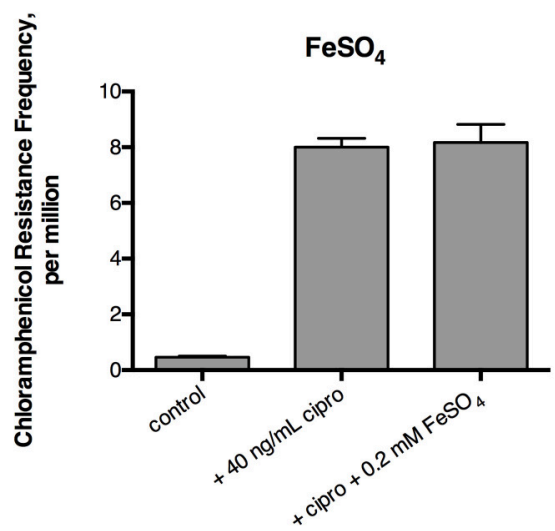

B

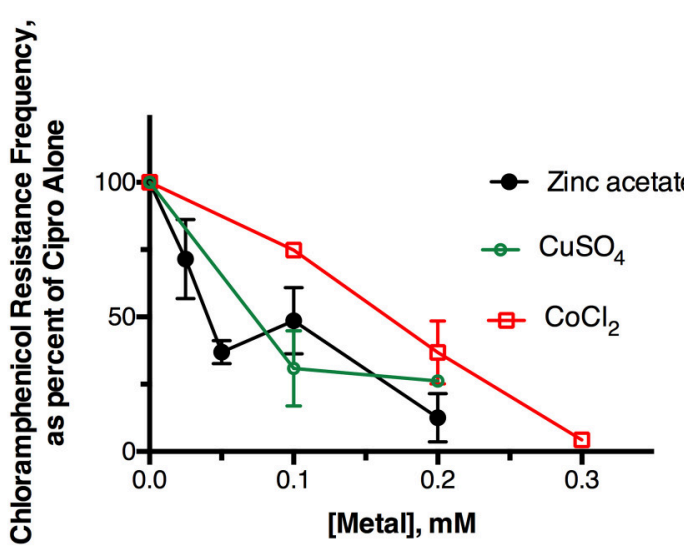

D

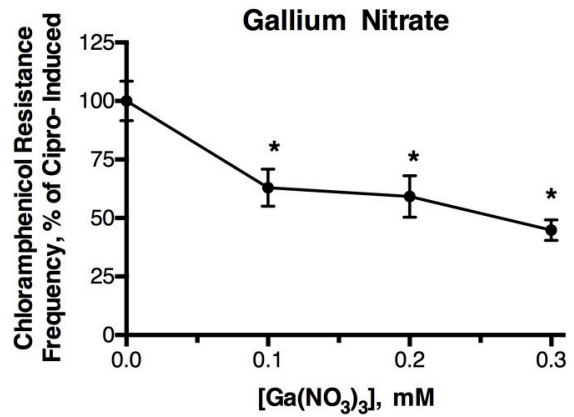

FIGURE 1 | Effect of zinc and other metals on ciprofloxacin-induced hypermutation in E_clo_Niagara. (A) Effect of ciprofloxacin and zinc on the chloramphenicol resistance frequency in $\mathrm{E}_{-}$clo_Niagara. (B) Comparison of zinc with $\mathrm{CuSO}_{4}$ and $\mathrm{CoCl}_{2}$ on ciprofloxacin -induced mutation frequency. To allow comparison of separate experiments, the results were expressed as a percent of the ciprofloxacin-induced mutation frequency for each experiment, then averaged. Each line on the graph shows the mean $\pm \mathrm{SD}$ of at least two separate experiments. (C) Lack of effect of $\mathrm{FeSO}_{4}$ on ciprofloxacin induced hypermutation. (D) Effect of gallium (III) nitrate on ciprofloxacin-induced hypermutation in E_clo_Niagara. *Significant compared to cipro alone by ANOVA; graph shown is the Mean \pm SD of 3 separate experiments, expressed as \% of cipro-induced.

the findings of Beaber et al. on SOS and horizontal gene transfer would apply to a different microbial system.

We tested whether the B-lactamase of Enterobacter E_clo_Niagara could be transferred to a susceptible STEC E. coli strain, EC43. EC43 also possessed its own plasmid, encoding the green fluorescence protein (GFP) and resistance to chloramphenicol. As described in section Materials and Methods, we induced the SOS response in each bacterial strain, then mixed together the 2 strains of bacteria at a 1:1 ratio, and, after allowing the mixtures to incubate for increasing periods of time, then plated aliquots on LB agar + chloramphenicol + ceftazidime. Plates were examined on the UV transilluminator box for green-fluorescing colonies resistant to both antibiotics.
In initial experiments where the E_clo_Niagara and EC43 were allowed to co-mingle for 3,4 , or $6 \mathrm{~h}$ before plating on antibiotic selective agar, no green fluorescing colonies were observed on the double-antibiotic plates. When the 2 species of bacteria were allowed to co-incubate for $20 \mathrm{~h}$, however, green colonies resistant to both antibiotics were observed in the condition in which the SOS-response was induced with ciprofloxacin (Figure 3 and Supplemental Figure 3A). Addition of $0.2 \mathrm{mM}$ zinc acetate blocked the appearance of the putative transconjugants when zinc was added to both bacteria along with ciprofloxacin (Figure 3A). Identification of the double-resistant, green colonies showed them to be $E$. coli that had acquired resistance to ceftazidime, rather than E_clo_Niagara that had 


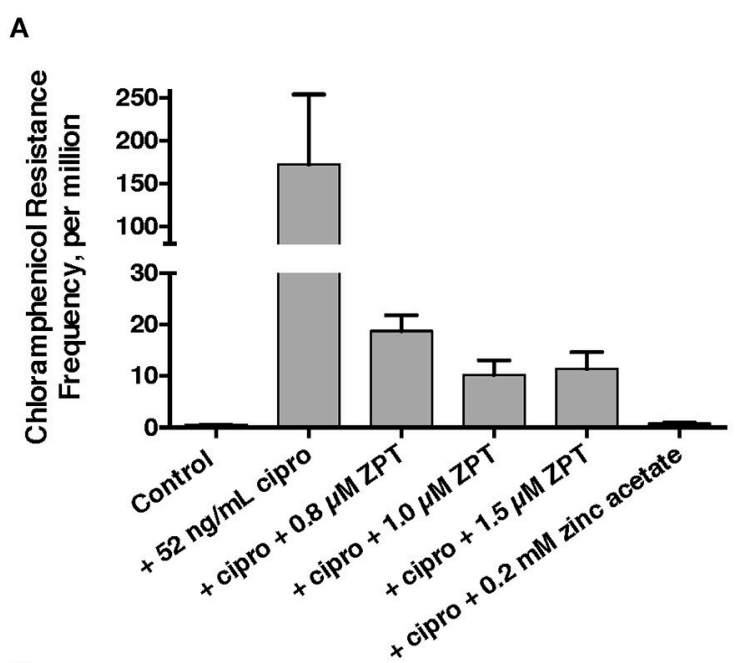

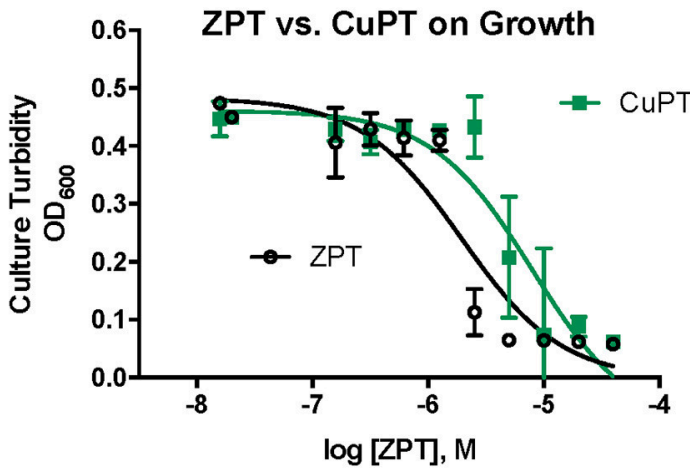

E

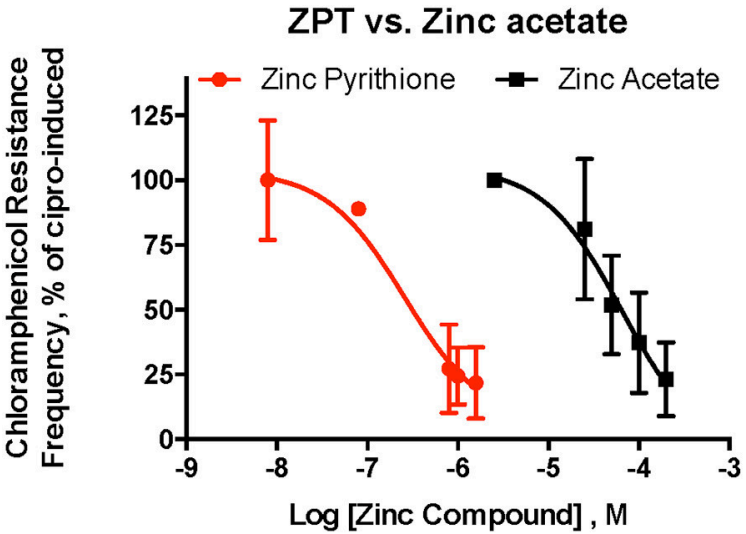

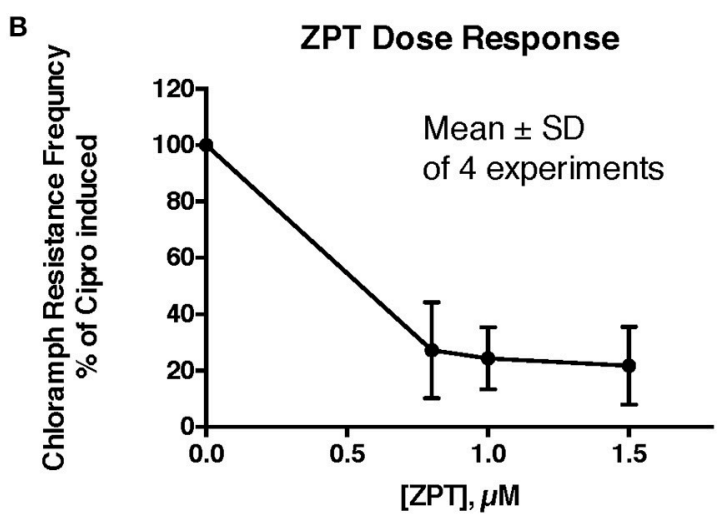

D

ZPT vs. CuPT

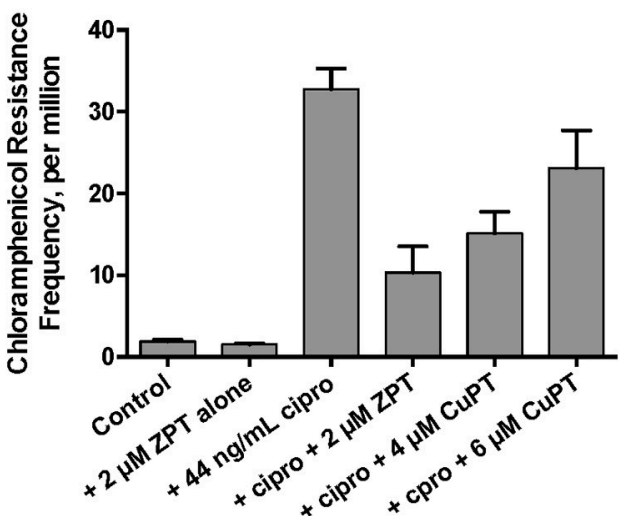

F 
A

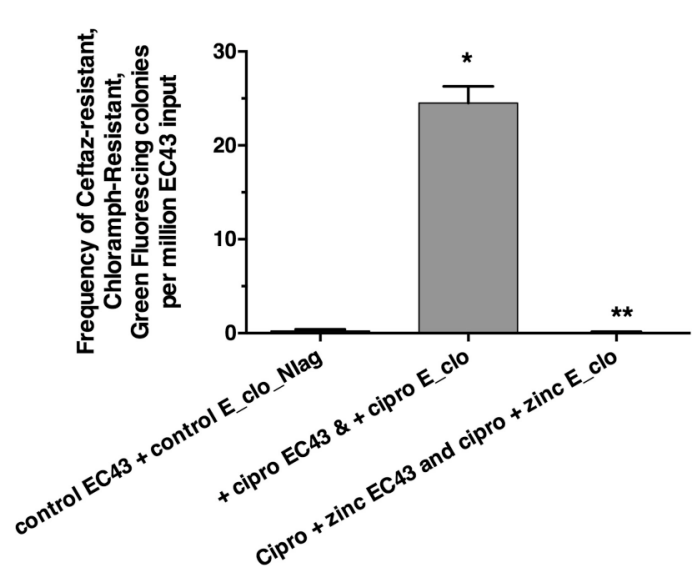

C

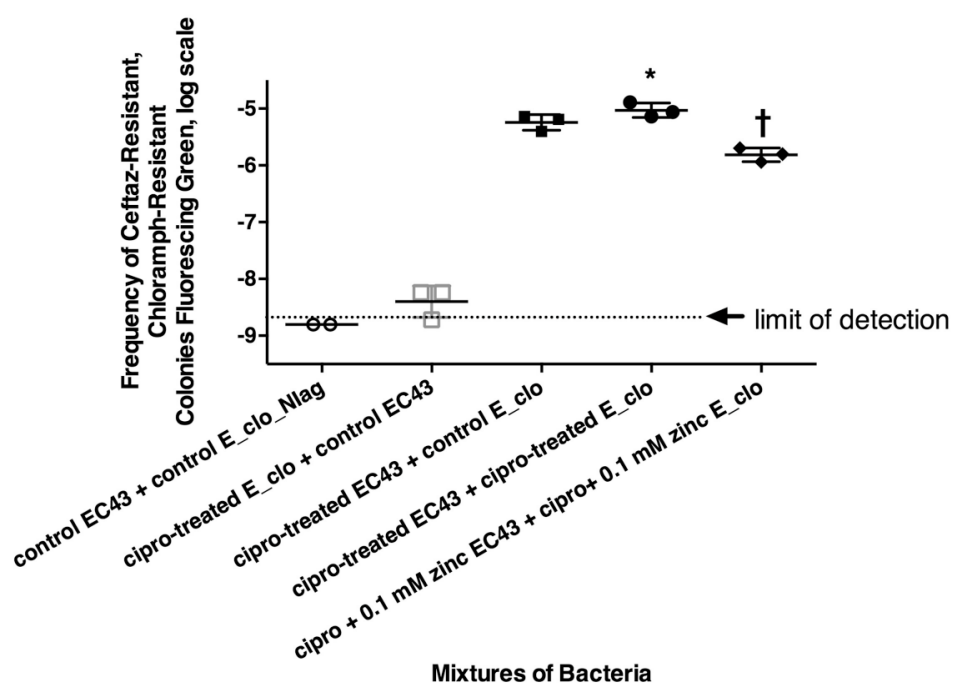

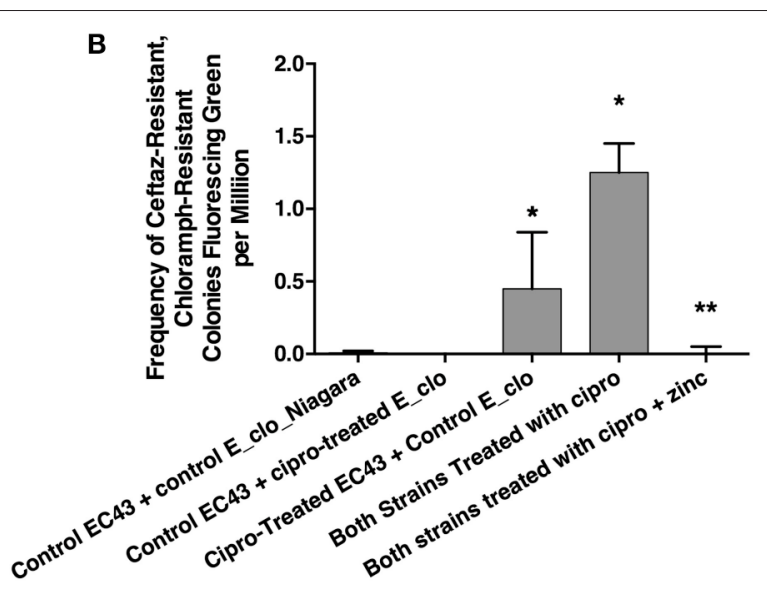

D

dsDNA in supernatant

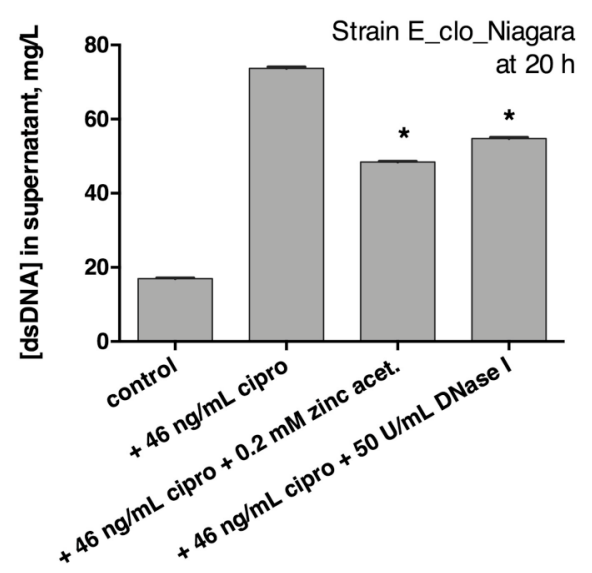

E

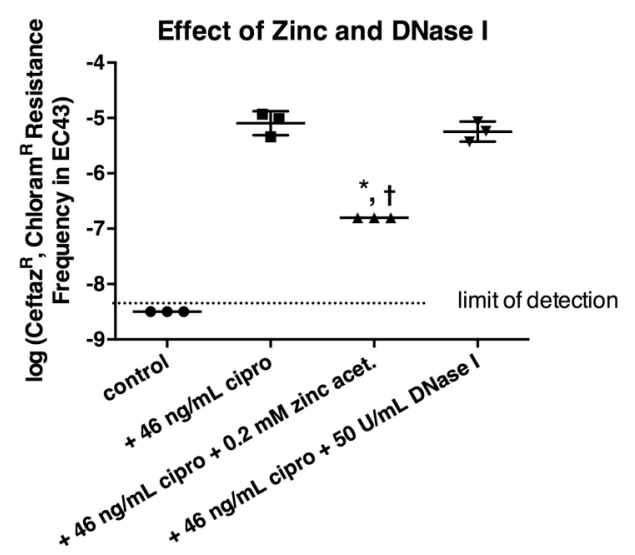

FIGURE 3 | Role of the SOS response in horizontal transfer of beta-lactam resistance from E_clo_Niagara to susceptible E. coli strain EC43. (A) Induction and inhibition of inter-species gene transfer. E_clo_Niagara and E. coli EC43 were both treated separately with ciprofloxacin to induce the SOS response, then mixed and allowed to co-incubate for $20 \mathrm{~h}$. The mixtures were plated on LB + ceftazidime + chloramphenicol, and examined under UV light for green fluorescing colonies resistant to both antibiotics. Since the colonies fitting the above description all tested as being $E$. coli, not Enterobacter, the frequency of emergence of such colonies was calculated relative to the number of EC43 bacteria placed into the original mixture. Zinc acetate concentration was $0.2 \mathrm{mM}$; *significantly increased compared to 
FIGURE 3 | control, **significantly decreased compared to the conditions receiving ciprofloxacin. (B) Effect of ciprofloxacin applied to E_clo_Niagara alone, E. coli EC43 alone, or both strains, on the horizontal gene transfer. The concentration of zinc used in (B), far-right column, was 0.2 mM; *significantly increased compared to control, ${ }^{\star \star}$ significantly decreased compared to the conditions receiving ciprofloxacin. (C) Effect of ciprofloxacin and zinc on horizontal gene transfer, with the transconjugant frequency expressed on a log scale. $0.1 \mathrm{mM}$ zinc was used in panel C; ${ }^{*}$ significantly increased compared to control, ${ }^{+}$significantly decreased compared to the conditions receiving ciprofloxacin. (D) Effect of zinc and DNase I on release of double-stranded DNA into culture supernatant; *significantly decreased compared to the plus cipro condition. (E) Effect of zinc and DNase I on frequency of emergence of putative transconjugants (green fluorescing colonies resistant to both antibiotics), showing that zinc, but not DNase, blocked the transfer of beta-lactam resistance to the $E$. coli strain. * significantly decreased compared to the condition receiving ciprofloxacin alone. ${ }^{\dagger}$ There were no $\mathrm{Ceftaz}^{\mathrm{R}}$, Chloram ${ }^{\mathrm{R}} \mathrm{E}$. coli colonies in the zinc-treated group, so the data points shown are calculated as if 1 colony had appeared.

acquired the plasmid encoding GFP and the chloramphenicol resistance marker. Control experiments with EC43 alone, not mixed with E_clo_Niagara, failed to show ciprofloxacin-induced acquisition of ceftazidime resistance (zero colonies observed in 10 separate experiments, all done in triplicate).

We next induced the SOS response in EC43 and E_clo_Niagara separately to try to determine if SOS induction was more important in the donor strain or the recipient strain. When only the donor strain, E_clo_Niagara, was treated with ciprofloxacin, putative transconjugants remained rare (Figures 3B,C, respectively). When only E. coli EC43 was subjected to SOS induction with ciprofloxacin, putative transconjugants were regularly observed in substantial numbers (Figures 3B,C). The greatest frequency of transconjugants was observed, however, when both the donor and the recipient strain were treated with ciprofloxacin (Figures 3B,C). Zinc acetate consistently blocked the SOS-induced transfer of B-lactam resistance phenotype. When the zinc concentration was reduced to $0.1 \mathrm{mM}$, however, the reversal of the SOS response was only partial (Figure 3C, right-hand set of points).

In the course of these experiments, we noted that induction of the SOS with ciprofloxacin, followed by a $20 \mathrm{~h}$ incubation, was accompanied by a release of DNA into the supernatant (Figure 3D; similar results were obtained with strain EC43 as well; data not shown). During the $20 \mathrm{~h}$ incubation, bacterial counts of both strains increased $\sim 3$-fold compared to the counts at the $4 \mathrm{~h}$ collection point, for both the antibiotictreated and untreated conditions. Therefore, the DNA release observed is not due to massive die-off of bacteria during the $20 \mathrm{~h}$ incubation. Addition of zinc acetate and DNase I both significantly reduced the amount of DNA detectable in bacterial supernatants (Figure 3D). Therefore, we tested whether addition of exogenous DNase I would block the horizontal transfer of $B$ lactam resistance to EC43. As shown in Figure 3E, DNase I had no effect on the frequency of appearance of the double-resistant transconjugant colonies in this assay, while zinc again showed its strong inhibitory effect. This also hinted that, although release of DNA into the supernatant occurred during our $20 \mathrm{~h}$ incubation, transfer of relevant DNA encoding antibiotic resistance likely does not occur by bulk release of DNA into the culture medium, but instead may require direct cell-to-cell contact.

The experiments of Figure 3 showed that the beta-lactam resistant phenotype from E_clo_Niagara, could be transferred to a susceptible E. coli strain when the SOS response was induced. We next tested whether we could detect the gene encoding the resistance had indeed been transferred to the recipient strain. The extended spectrum beta-lactamase (ESBL) gene family is large, but the ID Genomics company helped us narrow our focus to bla $a_{\mathrm{CTX}-\mathrm{M} 27}$. Using this knowledge, we constructed two sets of primers directed against CTX-M27 (section Materials and Methods and Table 2). PCR with both sets of primers revealed that DNA encoding CTX-M27 was present in the donor strain E_clo_Niagara and in the E. coli transconjugants, but not present in parental E. coli strain EC43. Quantitative PCR analysis from a typical experiment showed that the number of cycles to threshold, $\mathrm{C}_{\mathrm{t}}$, for amplification from the plasmid preparations from the various strains were: E_clo_Niagara: 28.0 \pm 0.7 ; EC43: NA (no amplification); Transconjugant 1: $32.2 \pm$ 1.0; Transconjugant 2, $27.3 \pm 0.5$; and Transconjugant 3, $35.8 \pm$ 0.3 , using the first set of primers shown in Table 2 . Similar results were observed using the second set of primers as well.

\section{RecA-ssDNA-Zinc Interactions}

Previously, we showed that zinc blocked the SOS-induced cleavage of the LexA repressor in live E. coli bacterial cells, and zinc also blocked RecA-mediated LexA cleavage in a cell-free assay using purified bacterial proteins plus cofactors (Bunnell et al., 2017). That previous work strongly suggested that zinc acted on RecA, as previously suggested by other authors (Lee and Singleton, 2004), but left open a narrow possibility that zinc might act on LexA, or on the protein-protein interface where RecA binds to LexA, possibly interfering with LexA's own proteolytic cleavage. To determine if zinc had effects on RecA alone, in the absence of LexA, we performed EMSAs using fluorescein-tagged ssDNA and purified RecA to see if zinc influenced the ability of RecA to bind to ssDNA (Svingen et al., 2001). Figure 4A shows the effect of adding increasing amounts of RecA protein in the presence of a fixed, $5 \mu \mathrm{M}$ concentration of fluorescent 38-mer ssDNA oligonucleotide. A marked upward shift in mobility was noted in the presence of $10 \mu \mathrm{M}$ RecA (lanes 4-6, 2:1 molar ratio of RecA to ssDNA), and the proportion of ssDNA migrating in this slower, upper band increased as the ratio of RecA to ssDNA was increased (Figure 4A, lanes 7-14). Figure 4A shows the results obtained in the absence of ATP- $\gamma$-S, but experiments in the presence of $0.3 \mathrm{mM}$ ATP- $\gamma$-S were also performed, and the densitometry scans of the fluorescence images, with and without ATP- $\gamma-S$, are shown in Figure 4B. Addition of zinc markedly reduced the proportion of ssDNA migrating as the upper band, and increased the amount of ssDNA in the original, unbound position (black arrows). Gels scans of Figure 4C and a parallel experiment done in the absence of ATP- $\gamma$-S are shown in Figure 4D. As shown in Figure 4D, the inhibitory effects of zinc on RecA binding were enhanced in the presence of ATP- $\gamma-S$, consistent with the 


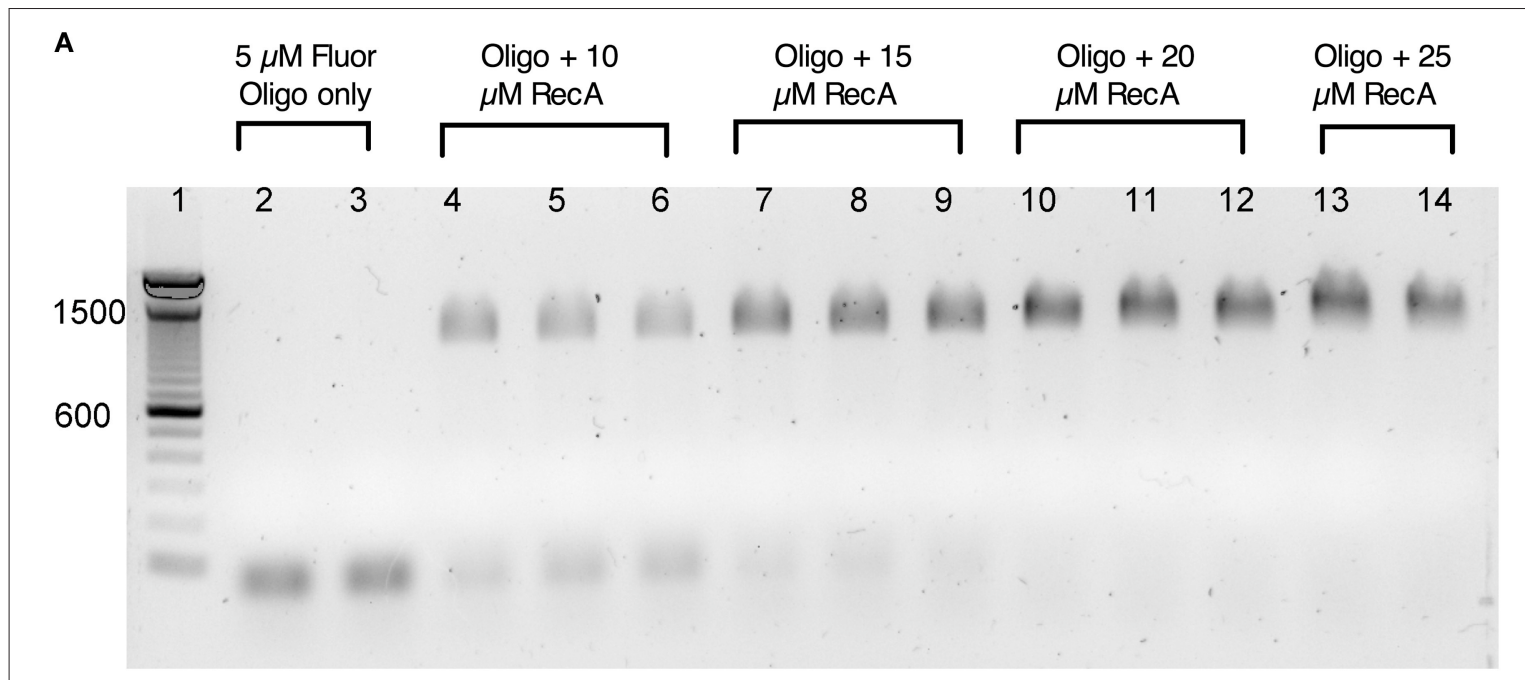

B

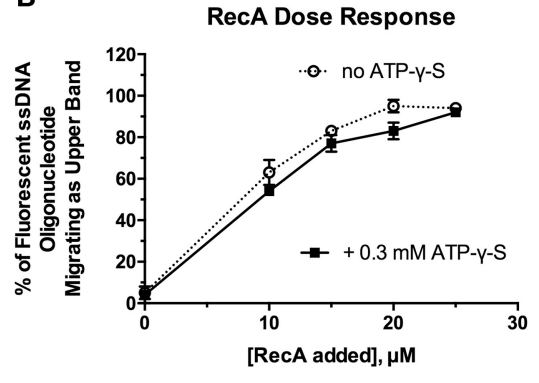

C

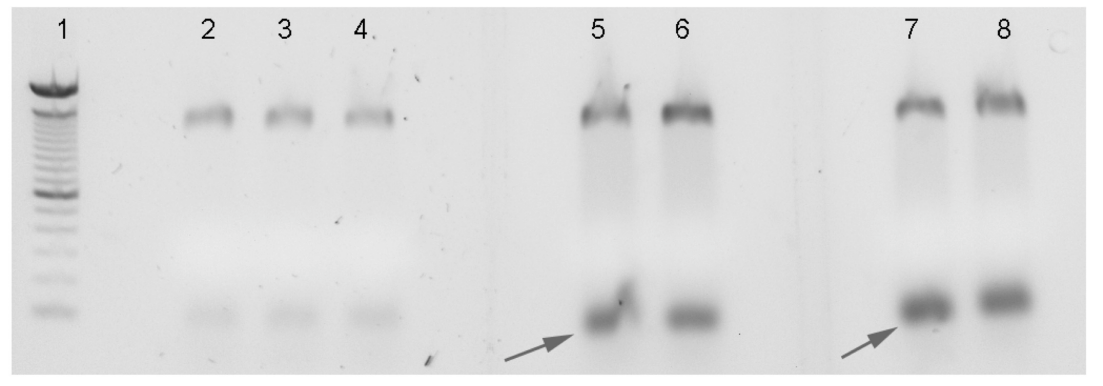

[ssDNA oligonucleotide] $=5 \mu \mathrm{M}$

D

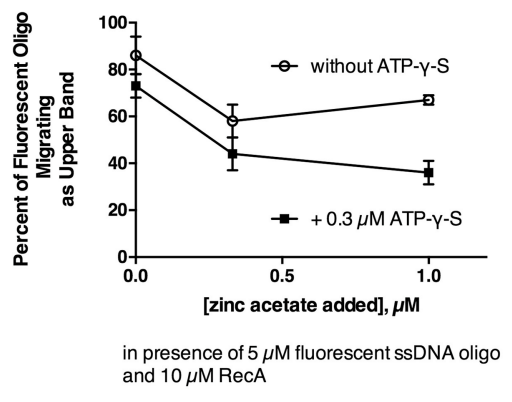

$\mathbf{E}$

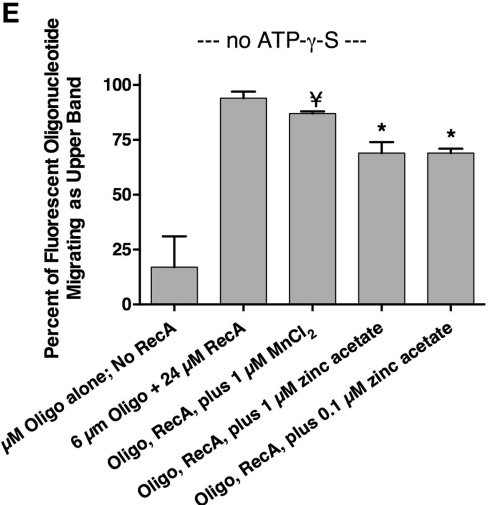

$\mathbf{F}$

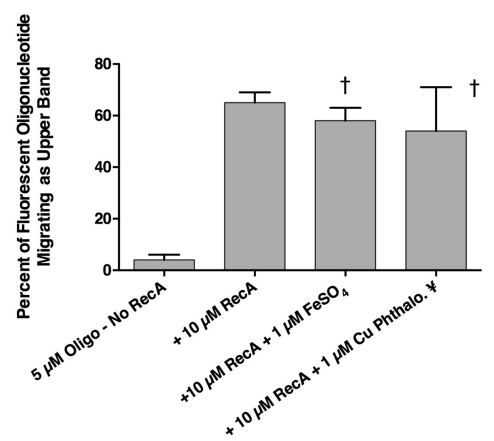

FIGURE 4 | Effect of zinc and other metals on the binding of RecA protein to a fluorescently labeled single-stranded DNA probe. Purified RecA protein and a 38-nucleotide single-stranded DNA probe labeled with fluorescein were used in an electrophoretic mobility shift assay (EMSA) in 1.5\% agarose gels. (A) Effect of increasing amounts of RecA on the migration of the fluorescently labeled ssDNA. Bands shown in (A,C) are the fluorescent ssDNA, but the digital image of the gel was "inverted" to produce dark bands on a white background. Lane 1, 100 bp dsDNA molecular weight ladder, with the bands 600 and 1,500 pairs indicated. Lanes 2 and 3, $5 \mu \mathrm{M}$ fluorescent oligonucleotide alone, with no RecA. Lanes 4-6, ssDNA + $10 \mu \mathrm{M}$ RecA; Lanes 7-9; ssDNA + 15 $\mu$ M RecA. Lanes 10-12, plus 20 $\mu$ M RecA; Lanes 13-14, with $25 \mu \mathrm{M}$ RecA. (B) Quantitative gel scan of the gel shown in (A), as well as an additional gel done in the presence of ATP- $\gamma$-S (latter gel not shown), showing that as the RecA protein is increased, the percent of the ssDNA migrating as the upper band increases. (C) Effect of zinc on the gel shift induced by RecA protein, in the presence of $0.3 \mathrm{mM}$ ATP- $\gamma$-S. Lane 1, 100 bp DNA MW ladder; Lanes 2-8 all received $5 \mu$ M ssDNA probe + 10 $\mu$ M RecA (2:1 ratio of RecA to ssDNA). Lanes $5 \& 6,+0.3 \mu \mathrm{M}$ zinc acetate; Lanes $7 \& 8,+1 \mu \mathrm{M}$ zinc acetate. Zinc was also cast into the appropriate lanes of the agarose gel as described in section Materials and Methods and Supplemental Figure 3. (D), quantitative gel scans of the gel shown in (C), plus another gel done in the absence of ATP- $\gamma$-S, are 
FIGURE 4 | graphed as a function of the concentration of added zinc. (E) Comparison of the effect of zinc on the gel shift assay, in contrast with the lack of effect of $\mathrm{MnCl}_{2}$. With RecA added to achieve a 4:1 ratio relative to ssDNA, the inhibitory effect of $1 \mu \mathrm{M}$ zinc was still evident, while $1 \mu \mathrm{M}$ MnCl 2 failed to inhibit the RecA-induced upward shift in the migration of the ssDNA probe; $¥$, not significant compared to Oligo + RecA, by ANOVA; *significant compared to Oligo + RecA; $p$ $<0.01$ by ANOVA. (F) Lack of effect of $1 \mu \mathrm{M} \mathrm{FeSO}_{4}$ and $1 \mu \mathrm{M}$ copper phthalocyanine tetrasulfonate ( $¥$ ), reported to be a RecA inhibitor, on the gel shift induced by RecA. ${ }^{\dagger}$ Not significant compared to RecA alone by ANOVA.

known role of ATP and ATP- $\gamma$-S in supporting the dissociation of bound RecA monomers from the ssDNA nucleofilament (Wigle et al., 2006). The inhibitory effects of zinc on RecA binding persisted even when higher concentrations of RecA were used in the assay (Figure 4E; 4:1 ratio of RecA to ssDNA). In contrast to the inhibitory effects of zinc, manganese did not inhibit ssDNA binding to RecA (Figure 4E), and neither did $1 \mu \mathrm{M} \mathrm{FeSO}$ (Figure 4F). Surprisingly, the newly discovered RecA inhibitor, copper phthalocyanine tetrasulfonate, also failed to inhibit RecA-ssDNA binding in this assay (Figure 4F). The $1 \mu \mathrm{M}$ concentration used in Figure $4 \mathrm{~F}$, however, was lower than the $10-15 \mu \mathrm{M}$ concentrations used in the report by Alam et al. however (Alam et al., 2016). Nevertheless, Figure 4 shows that RecA binding to ssDNA can be readily detected using a fluorescently labeled oligonucleotide in agarose gels, and that zinc inhibits RecA binding to ssDNA at low, $1 \mu \mathrm{M}$ concentrations, while iron, manganese, and a phthalocyanine tetrasulfonate compound did not. In addition, although zinc acts to block RecAinduced LexA cleavage (Bunnell et al., 2017), the presence of LexA is not necessary to observe the effects of zinc in vitro. Our results suggest that zinc blocks LexA cleavage by preventing the formation of the active RecA-ATP-ssDNA nucleofilament.

\section{DISCUSSION}

Although the SOS response has been discussed in the molecular biology literature for over 40 years (Radman, 1975), appreciation of the role of the SOS pathway in generation of antibiotic resistance has been very slow to percolate into the fields of clinical microbiology and infectious diseases. Recently, however, several laboratories have shown that sublethal concentrations of antibiotics can not only induce the SOS response, but also trigger the emergence of resistance to other, unrelated antibiotics (Kohanski et al., 2010; Song et al., 2016). In addition, our laboratory and others have shown that SOSinduced hypermutation, resulting in the emergence of antibiotic resistance, can be triggered by a wider array of compounds than classical inducers such as mitomycin C, ciprofloxacin, and UV light. The SOS response is induced in E. coli by oxidant stress and by a wide variety of drugs used in human and veterinary medicine, including some antiviral drugs, cancer chemotherapy agents, antimetabolites, arsenic compounds, the herbicide paraquat, and many other antibiotics, including those used for growth promotion in farm animals (Baharoglu and Mazel, 2011; Bunnell et al., 2017). We began studying zinc because it is an inhibitor of Shiga toxin (Stx) production in STEC, but later learned that zinc was blocking the SOS response itself, not just Stx toxin release. We showed that zinc, but not most other metals tested, blocked SOS-induced hypermutation to antibiotics such as rifampin and trimethoprim, in E. coli and
Klebsiella pneumoniae (Bunnell et al., 2017). As expected from the work of others (Cirz and Romesberg, 2006; Recacha et al., 2017), the hypermutation response, and zinc's inhibitory effects on SOSinduced mutation were dependent on RecA, a key sensor of DNA damage and initiator of the SOS response (Bunnell et al., 2017).

In this study, we first tested whether the inhibitory effects of zinc could be observed in another member of the Enterobacteriaceae family, E. cloacae. Zinc blocked ciprofloxacin-induced hypermutation, reducing the emergence of chloramphenicol resistance, while cobalt, copper, and gallium showed similar, but weaker activity (Figure 1). We also showed that a zinc ionophore, zinc pyrithione (ZPT), blocked SOSinduced hypermutation with an inhibitory concentration 50\% $\left(\mathrm{IC}_{50}\right) \sim 100$-fold lower than zinc salts. This high potency compares favorably with other RecA inhibitors that have been proposed (Lee et al., 2005; Wigle et al., 2009; Alam et al., 2016). Although ZPT can have some toxicity toward mammalian cells (Priestley and Brown, 1980), it has been cleared by the United States Food and Drug Administration (FDA) for use on the skin at concentrations up to $0.25 \%(7.8 \mathrm{mM})$ in "leave on" products such as lotions, and $2 \%(63 \mathrm{mM})$ in "rinse-off" products such as shampoos (Schwartz, 2016). Older literature on ZPT tended to focus on its antifungal effects (Pierard-Franchimont et al., 2002; Reeder et al., 2011), but more recent reports emphasize the activity of ZPT against bacteria as well (Schwartz, 2016).

Inspired by the work of Beaber et al., we tested whether induction of the SOS response would trigger horizontal gene transfer from a ß-lactam resistant, ESBL-producing Enterobacter strain to a sensitive $E$. coli strain. We were able to demonstrate transfer of the $ß$-lactamase gene to the E. coli EC43 strain after a prolonged, $20 \mathrm{~h}$, co-incubation. Although we have referred to the newly-resistant EC43 colonies as "putative transconjugants," we have not conclusively shown that the mechanism of transfer of the B-lactamase is by conjugation. Jung tested a panel of 15 Enterobacter aerogenes strains for their ability to conjugate with E. coli and found only 1 of the 15 strains capable of doing so (Jung, 2014). Indeed, when we tested for transfer of the AmpC chromosomal ß-lactamase from a different E. cloacae strain (BAA-1143) to EC43, putative transconjugants were either much rarer, or, in some experiments, not observed at all (data not shown). The rare transconjugants observed with strain BAA1143 as the donor were also unstable genetically, and gradually lost their $ß$-lactam resistance with repeated passage.

PCR analysis of the E. coli transconjugants that had acquired ceftazidime resistance revealed that the CTX-M27 beta-lactamase gene was present in the plasmid DNA. Therefore, it may be more accurate to describe these resistant $E$. coli strains as transformants (Chen and Dubnau, 2004) rather than as transconjugants. Classically, conjugation proceeds via transfer of ssDNA via a 
conjugation pilus to the recipient strain, whereas transformation (such as by electroporation) is usually more efficient with doublestranded plasmid DNA. McCollister et al. recently described in vivo acquisition of the CTX-M27 plasmid by a Salmonella enterica strain in a relapsed infection (McCollister et al., 2016). In that case, the patient's Salmonella strain was initially susceptible to the $3^{\text {rd }}$-generation cephalosporins and the patient was treated with ceftriaxone. After relapse, however, the Salmonella strain was resistant to ceftriaxone, and comparison of the two strains allowed the investigators to determine that the Salmonella had acquired the CTX-M27 beta-lactamase, incorporated into a plasmid. The resistance element in Salmonella could be transferred back into a susceptible E. coli strain, where it also was located on a plasmid. Although we have not conducted the detailed DNA sequencing done by McCollister et al., we believe that our results may reflect a similar process, but with gene transfer between E. cloacae and E. coli. Notably, betalactam antibiotics such as ceftriaxone do induce the SOS response (Drago et al., 2004; Maiques et al., 2006), and so SOS induction could have played a role in the in vivo transfer of the resistance gene in the GI tract of the patient described by McCollister et al. It is also notable that the work of McCollister et al. (2016) and Beaber et al. (2003), and the work in this study all used wildtype enteric pathogens in their studies of DNA transfer between species. Over-reliance on highly passaged laboratory strains of $E$. coli in the past may have prevented earlier recognition of these phenomena.

Although DNA, especially ssDNA, is often degraded upon entry into $E$. coli cells via the competence (Com) gene locus (Finkel and Kolter, 2001; Palchevskiy and Finkel, 2006), it is possible that when the SOS is induced, RecA becomes abundant enough that it is able to catalyze recombination of ssDNA with the recipient cell's DNA before the newly acquired DNA is degraded (Beaber et al., 2003). If so, this would explain why transfer of the $B$-lactam resistance was greatest when the SOS response was induced in the recipient as well as the donor strain (Figures 3B,C). While the mechanism of the DNA transfer is not clear, what is clear is that transfer is triggered by the SOS response, and that the transfer is strongly inhibited by zinc, raising the possibility that zinc compounds could be used to block horizontal transfer of antibiotic resistance in situations where this gene transfer would be undesirable.

Other authors have suggested that a good way to exploit RecA inhibitors under development would be to reverse pre-existing antibiotic resistance, i.e., in strains already resistant to antibiotics such as the quinolones (Alam et al., 2016; Recacha et al., 2017).

\section{REFERENCES}

Alam, M. K., Alhhazmi, A., Decoteau, J. F., Luo, Y., and Geyer, C. R. (2016). RecA inhibitors potentiate antibiotic activity and block evolution of antibiotic resistance. Cell Chem. Biol. 23, 381-391. doi: 10.1016/j.chembiol.2016.02.010

Baharoglu, Z., and Mazel, D. (2011). Vibrio cholerae triggers SOS and mutagenesis in response to a wide range of antibiotics: a route towards multiresistance. Antimicrob. Agents Chemother. 55, 2438-2441. doi: 10.1128/AAC.01549-10
We suggest that a more effective strategy would be to use RecA inhibitors, including zinc compounds, to prevent the emergence of resistance in situations where sensitive microbes are still present, but induction of the SOS response would be expected or inevitable, such as when UV light, ionizing radiation, cytotoxic cancer chemotherapy, or other SOS-inducing drugs are used (Rutala et al., 2010).

Although zinc-containing RecA inhibitors show promise for preventing emergence of antibiotic resistance, a concern is whether zinc resistance could emerge as a bacterial countermeasure. Zinc resistance seems to be uncommon in bacteria, but has been reported (McHugh et al., 1975; Hau et al., 2017). Therefore, if RecA inhibitors are ever adopted for use in human or veterinary medicine, animal agriculture, or food processing, prudence and stewardship in use of these RecA inhibitors may become as necessary as prudence and stewardship in the use of antibiotics themselves.

\section{AUTHOR CONTRIBUTIONS}

MC did the initial hypermutation experiments with E. cloacae and began the inter-species gene transfer experiments. MO did all of the experiments with zinc ionophores. JC completed inter-species gene transfer experiments, performed the EMSA's, the PCR experiments, and wrote the manuscript. MS helped design experiments, reviewed the manuscript, and made helpful critiques.

\section{FUNDING}

This work was supported by funds from the Dept. of Internal Medicine, University at Buffalo, and by support from the CLIMB UP program for the summer stipend for MO.

\section{ACKNOWLEDGMENTS}

We thank Elena Rechkina, Ph.D., ID Genomics, for help in determining the type of $\beta$-lactamase present in E_clo_Niagara. We also thank Eric DeCourcey for assistance in ordering supplies and reagents.

\section{SUPPLEMENTARY MATERIAL}

The Supplementary Material for this article can be found online at: https://www.frontiersin.org/articles/10.3389/fcimb. 2018.00410/full\#supplementary-material
Bao, V. W., Lui, G. C., and Leung, K. M. (2014). Acute and chronic toxicities of zinc pyrithione alone and in combination with copper to the marine copepod Tigriopus japonicus. Aquat. Toxicol. 157, 81-93. doi: 10.1016/j.aquatox.2014. 09.013

Beaber, J. W., Hochhut, B., and Waldor, M. K. (2003). SOS response promotes horizontal dissemination of antibiotic resistance genes. Nature 427, 72-74. doi: 10.1038/nature 02241 
Bonnet, R. (2004). Growing group of extended-spectrum $\beta$-lactamases: the CTX-M enzymes. Antimicrob. Agents Chemother. 48, 1-14. doi: 10.1128/AAC.48.1.1-14.2004

Bunnell, B. E., Escobar, J. F., Bair, K. L., Sutton, M., and Crane, J. (2017). Zinc blocks SOS-induced hypermutation via inhibition of RecA in Escherichia coli. PLoS ONE 12:e0178303. doi: 10.1371/journal.pone.0178303

Chen, I., and Dubnau, D. (2004). DNA uptake during bacterial transformation. Nat. Rev. Microbiol. 2:241. doi: 10.1038/nrmicro844

Cirz, R. T., and Romesberg, F. E. (2006). Induction and inhibition of ciprofloxacin resistance-conferring mutations in hypermutator bacteria. Antimicrob. Agents Chemother. 50, 220-225. doi: 10.1128/AAC.50.1.220-225.2006

Crane, J. K., Broome, J. E., Reddinger, R. M., and Werth, B. B. (2014). Zinc protects against shiga-toxigenic Escherichia coli by acting on host tissues as well as on bacteria. BMC Microbiol. 14:145. doi: 10.1186/1471-2180-14-145

Drago, L., De Vecchi, E., Nicola, L., Tocalli, L., and Gismondo, M. R. (2004). Effect of moxifloxacin on bacterial pathogenicity factors in comparison with amoxicillin, clarithromycin and ceftriaxone. J. Chemother. 16, 30-37. doi: 10.1179/joc.2004.16.1.30

Finkel, S. E., and Kolter, R. (2001). DNA as a nutrient: novel role for bacterial competence gene homologs. J. Bacteriol. 183, 6288-6293. doi: 10.1128/JB.183.21.6288-6293.2001

Goodman, M. F. (2002). Error-prone repair DNA polymerases in prokaryotes and eukaryotes. Annu. Rev. Biochem. 71, 17-50. doi: 10.1146/annurev.biochem.71.083101.124707

Hau, S. J., Frana, T., Sun, J., Davies, P. R., and Nicholson, T. L. (2017). Zinc Resistance within swine-associated methicillin-resistant Staphylococcus aureus isolates in the United States is associated with multilocus sequence type lineage. Appl. Environ. Microbiol. 83:e00756-17. doi: 10.1128/AEM.00756-17

Jung, C. M. (2014). Dissemination of bacterial fluoroquinolone resistance in two multidrug-resistant enterobacteriaceae. J. Mol. Microbiol. Biotechnol. 24, 130-134. doi: 10.1159/000362278

Kohanski, M. A., Depristo, M. A., and Collins, J. J. (2010). Sublethal antibiotic treatment leads to multidrug resistance via radical-induced mutagenesis. Mol. Cell 37, 311-320. doi: 10.1016/j.molcel.2010.01.003

Lee, A. M., Ross, C. T., Zeng, B.-B., and Singleton, S. F. (2005). A molecular target for suppression of the evolution of antibiotic resistance: inhibition of the Escherichia coli RecA protein by N6-(1-Naphthyl)-ADP. J. Med. Chem. 48, 5408-5411. doi: 10.1021/jm050113z

Lee, A. M., and Singleton, S. F. (2004). Inhibition of the Escherichia coli RecA protein: zinc (II), copper (II) and mercury (II) trap RecA as inactive aggregates. J. Inorg. Biochem. 98, 1981-1986. doi: 10.1016/j.jinorgbio.2004.08.018

Maiques, E., Úbeda, C., Campoy, S., Salvador, N., Lasa, I., Novick, R. P., et al. (2006). $\beta$-Lactam antibiotics induce the SOS response and horizontal transfer of virulence factors in Staphylococcus aureus. J. Bacteriol. 188, 2726-2729. doi: 10.1128/JB.188.7.2726-2729.2006

McCollister, B., Kotter, C. V., Frank, D. N., Washburn, T., and Jobling, M. G. (2016). Whole genome sequencing identifies in vivo acquisition of a blaCTX-M-27-encoding IncFII transmissible plasmid as the cause of ceftriaxone treatment failure for an invasive Salmonella enterica serovar Typhimurium infection. Antimicrob. Agents Chemother. 60, 7224-7235. doi: 10.1128/AAC.01649-16

McHugh, G. L., Moellering, R., Hopkins, C., and Swartz, M. (1975). Salmonella typhimurium resistant to silver nitrate, chloramphenicol, and ampicillin: a new threat in burn units? Lancet 305, 235-240. doi: 10.1016/S0140-6736(75)91138-1

Nautiyal, A., Patil, K. N., and Muniyappa, K. (2014). Suramin is a potent and selective inhibitor of Mycobacterium tuberculosis RecA protein and the SOS response: RecA as a potential target for antibacterial drug discovery. J. Antimicrob. Chemother. 69, 1834-1843. doi: 10.1093/jac/dku080
Palchevskiy, V., and Finkel, S. E. (2006). Escherichia coli competence gene homologs are essential for competitive fitness and the use of DNA as a nutrient. J. Bacteriol. 188, 3902-3910. doi: 10.1128/jb.01974-05

Pierard-Franchimont, C., Goffin, V., Decroix, J., and Pierard, G. E. (2002). A multicenter randomized trial of ketoconazole $2 \%$ and zinc pyrithione $1 \%$ shampoos in severe dandruff and seborrheic dermatitis. Skin Pharmacol. Appl. Skin Physiol. 15, 434-441. doi: 10.1159/000066452

Priestley, G. C., and Brown, J. C. (1980). Acute toxicity of Zinc pyrithione to human skin cells in vitro. Acta Derm. Venereol. 60, 145-148.

Radman, M. (1975). "SOS repair hypothesis: phenomenology of an inducible DNA repair which is accompanied by mutagenesis," in Molecular Mechanisms for Repair of DNA, eds P. C. Hanawalt and R. B. Setlow (Boston, MA: Springer), 355-367.

Recacha, E., Machuca, J., Díaz de Alba, P. D., Ramos-Güelfo, M., Docobo-Pérez, F., Rodriguez-Beltrán, J., et al. (2017). Quinolone resistance reversion by targeting the SOS response. mBio 8:e00971-17. doi: 10.1128/mBio.00971-17

Reeder, N. L., Xu, J., Youngquist, R. S., Schwartz, J. R., Rust, R. C., and Saunders, C. W. (2011). The antifungal mechanism of action of zinc pyrithione. Brit. J. Dermatol. 165(Suppl. 2), 9-12. doi: 10.1111/j.1365-2133.2011.1 0571.x

Rutala, W. A., Gergen, M. F., and Weber, D. J. (2010). Room decontamination with UV radiation. Infect. Control Hospital Epidemiol. 31, 1025-1029. doi: $10.1086 / 656244$

Schwartz, J. R. (2016). Zinc pyrithione: a topical antimicrobial with complex pharmaceutics. J. Drugs Dermatol. 15, 140-144.

Song, L. Y., Goff, M., Davidian, C., Mao, Z., London, M., Lam, K., et al. (2016). Mutational consequences of ciprofloxacin in Escherichia coli. Antimicrob. Agents Chemother. 60, 6165-6172. doi: 10.1128/aac.01415-16

Svingen, R., Takahashi, M., and Åkerman, B. (2001). Gel-shift assays: migrative dissociation of a RecA-oligonucleotide complex during electrophoresis in hydroxyethylated agarose gels. J. Phys. Chem. B 105, 12879-12893. doi: $10.1021 /$ jp011674e

Szczepanowski, R., Linke, B., Krahn, I., Gartemann, K.-H., Gützkow, T., Eichler, W., et al. (2009). Detection of 140 clinically relevant antibiotic-resistance genes in the plasmid metagenome of wastewater treatment plant bacteria showing reduced susceptibility to selected antibiotics. Microbiology 155, 2306-2319. doi: 10.1099/mic.0.028233-0

Wigle, T. J., Lee, A. M., and Singleton, S. F. (2006). Conformationally selective binding of nucleotide analogues to Escherichia coli RecA: a ligandbased analysis of the RecA ATP binding site. Biochemistry 45, 4502-4513. doi: 10.1021/bi052298h

Wigle, T. J., Sexton, J. Z., Gromova, A. V., Hadimani, M. B., Hughes, M. A., Smith, G. R., et al. (2009). Inhibitors of RecA activity discovered by high-throughput screening: cell-permeable small molecules attenuate the SOS response in Escherichia coli. J. Biomol. Screen. 14, 1092-1101. doi: $10.1177 / 1087057109342126$

Conflict of Interest Statement: The authors declare that the research was conducted in the absence of any commercial or financial relationships that could be construed as a potential conflict of interest.

Copyright (c) 2018 Crane, Cheema, Olyer and Sutton. This is an open-access article distributed under the terms of the Creative Commons Attribution License (CC BY). The use, distribution or reproduction in other forums is permitted, provided the original author(s) and the copyright owner(s) are credited and that the original publication in this journal is cited, in accordance with accepted academic practice. No use, distribution or reproduction is permitted which does not comply with these terms. 